\title{
Palaeogeographical heritage of the Permian Period in the network of protected areas and museums of the Perm Region
}

\author{
Yuliya Glazyrina ${ }^{1,2}$, Larisa Zhuzhgova $^{3}$, Sergey Buzmakov ${ }^{1}$, and Pavel Sannikov ${ }^{1}$ \\ ${ }^{1}$ Perm State University, Biogeocenology and Nature Protection Department, 614000 Perm, Russia \\ ${ }^{2}$ Perm Regional Museum, Natural History Department, 614000 Perm, Russia \\ ${ }^{3}$ Perm Regional Museum, Natural History Collections, 614000 Perm, Russia
}

\begin{abstract}
Article presents an overview of palaeogeographical heritage of the Permian Period in the network of protected areas and museums of the Perm Region. Permian Period, received its name after the city of Perm in Russia, includes the so-called "Main Permian Field". It contains two types of palaeogeorgaphical heritage: marine and terrestrial. The representation of palaeogeographical objects of different types is analysed for the geoheritage of the protected areas in situ. Geoheritage ex situ, in the network of the regional museum collections, is estimated from the representative aspects. Recommendations on optimization of the protected areas network and museum acquisition is given from the point of view of paleo-geographical heritage objects representation.
\end{abstract}

\section{Introduction}

Objects of palaeogeographical heritage of the Permian Period in the territory of the Perm Region has the international significance as they refer to the so-called "Main Permian Field", sediments that have become a basis for the Permian Period discovery, now included into the International Stratigraphical and Geochronological Timescales [1, 2, 3]. Permian System and Period was named after the city of Perm in Urals, Russia, by the Scottish geologist Sir Roderick Murchison in 1841 [4, 5, 6]. The Permian (299-251 million years ago) is the time of the of terrestrial and marine sedimentation process, which is described all over the world. The most significant of the Permian deposits and outcrops, including boundaries of stratigraphic subdivisions and Global Stratotype Section and Point (GSSP) are protected areas.

Permian outcrops in the territory of the modern-day Perm Region are included into the regional network of the protected areas. It refers to the palaeogeoraphical heritage in situ, while geological and palaeontological natural history museum collections across the Perm Region represents geoheritage ex situ. To provide the most efficient model of geoheritage research, preservation and presentation there should be a balance rather than a substitution of both.

* Corresponding author: glazyrina_yuliya@mail.ru 


\subsection{Geographical distribution of Permian deposits in the world}

The Permian Period was named after the city of Perm, Western Urals, Russia. This name is a geographical toponym, given by the Scottish geologist Sir Roderick Impey Murchison in 1841, after a 20,000-km-long expedition across the European part of Russia and the Ural Mountains [2, 5, 6, 7]. Since late 1800s, the Permian had been widely used in stratigraphical nomenclature.

For quite some time, the Permian was divided into two parts: Lower and Upper Permian. Currently, a tripartite subdivision is used - the Lower Permian, the stratotype of which is situated in the western Urals, Middle Permian with the stratotype in the southwestern United States and the Upper Permian with the stratotype in southern China.

Permian terrestrial deposits are generally correlated with the former Pangaea supercontinent, while evaporites and marine deposits connected to lagoons and shallow seas tend to be found along its margins. Permian deposits are observed on all continents, with the "Main Permian Field" in the Pre-Urals in Russia (mostly Perm Region, as well as Bashkiria, Chelyabinsk Region, Orenburg Region and others).

The GSSP of the Lower Permian, Asselian Stage, is in the valley of the River Aidaralash, near Aqtube, the Ural Mountains [3, 8]. The Subcommission on Permian Stratigraphy of the International Commission on Stratigraphy co-ordinated working groups on the approval of the Permian GSSP. The latest one was the ratification of the Sakmarianbase GSSP (Lower Permian) in the southern Urals, Russia, in 2018 [3, 9].

The Middle Permian GSSP of the Guadalupian was ratified in the early 2000s. All GSSPs, Roadian, Wordian and Capitanian sections, are located in the Guadalupe Mountains National Park, Texas, USA [3, 10].

The Upper Permian, the Lopingian, is based on the GSSPs of the Changhsingian and Wuchiapingian stages were ratified in 2004 and 2005, respectively [1, 3]

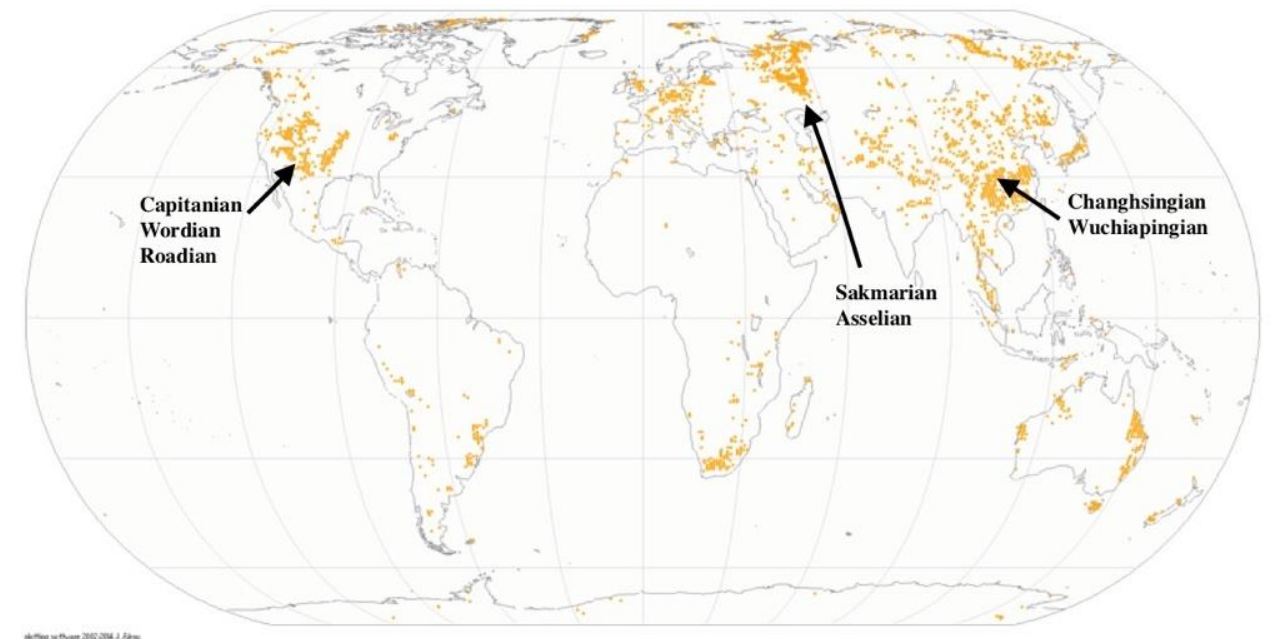

Fig. 1. Map of Permian palaeographical fossil sites around the world, with the GSSP (based on the Fossil Works data base, 2002-2014; accessed February 20, 2020).

\subsection{Palaeogeographical and geological heritage in the Perm Region}

The deposits of the Permian System are united into the "Main Perm Field", a historically significant area of distribution of sedimentary rocks and fossils of Permian Period, which are cropped out to the surface. Palaeogeographical and geological heritage of the Permian 
in the Perm Region could be divided into two types of objects. The first type contains objects in situ, which are located at the (1) protected areas, (2) territories suggested for the protected areas, (3) territories that contain geoheritage objects but not recommended for the protection. The second type contains objects from the museum collections. They could be divided into two main groups: (1) geological collections, (2) paleontological collections, the last one consists of different types such as palaeoentomological, palaeobotanical, etc.

\section{Overview of protected areas for the Permian Period palaeogeographical heritage in situ}

The network of protected areas in the Perm Region consists of two strict nature reserves of federal level, 259 protected areas of regional significance and 102 protected areas of local significance [10-14].

Protected areas of geological importance in the Perm Region can be divided into several types: tectonic, stratigraphical, palaeontological, cosmological, geomorphological, petrographic, mineralogical, hydrogeological, mining-geological and karstological [14].

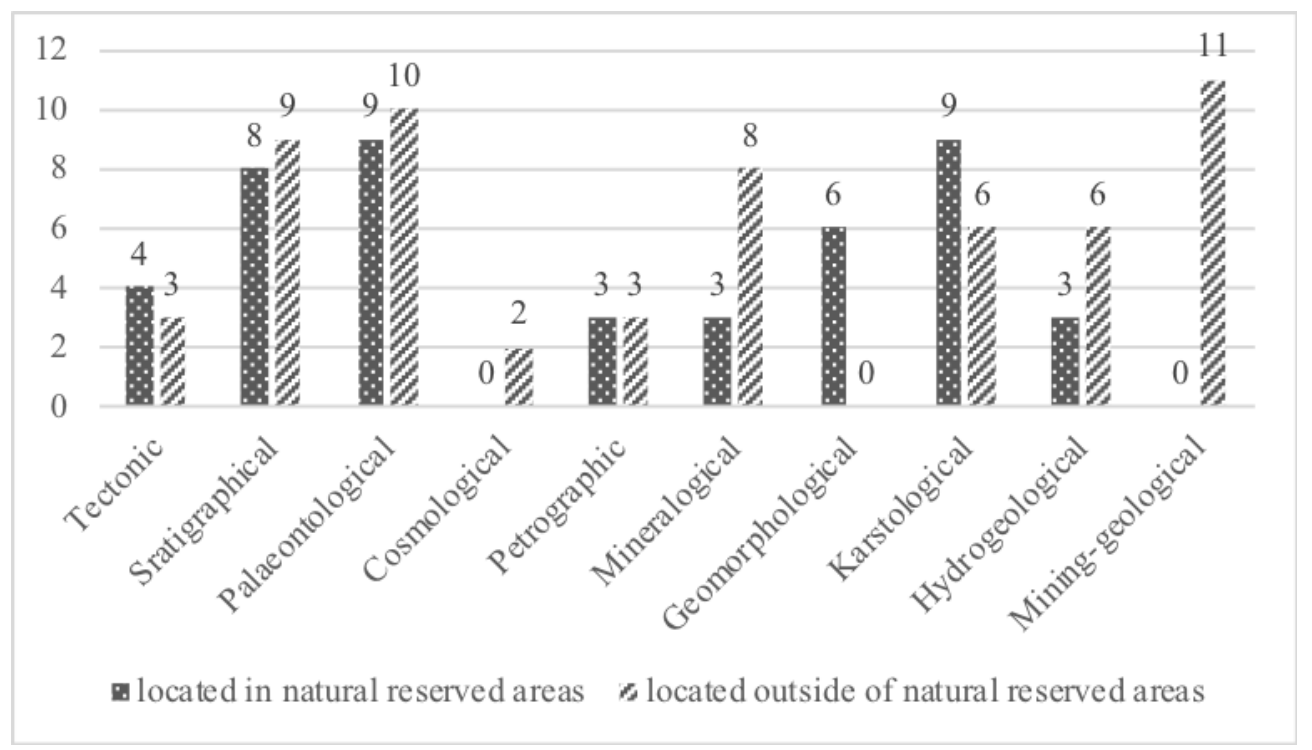

Fig. 2. Palaeogeographical and geological monuments of various types in the network of protected areas [15].

At least 45 of protected areas are devoted to the palaeogeographical and geological heritage, $3 / 5$ of palaeogeographical heritage objects of the Permian Period are included into the paleontological, stratigraphic, mineralogical and karstological monuments. More than half of protected areas, which include objects of the Permian Period, have a specialized geological profile (geomorphological, karstological, etc.), the other part of palaeogeographical heritage objects of the Permian belong to the complex protected areas.

Objects of palaeogeographical and geological heritage of the Permian are classified as two main types of sediments: marine and terrestrial.

\subsection{Marine Permian outcrops on the protected areas}

Marine sediments are concentrated to the Pre-Ural foreland basin, which stretches submeridionally along the Urals. The most significant sections of the Lower Permian are 
marine sediments: the brine section (Goniatida, Nautiloidea, Anthozoa), the Polazna section (Stromatolites), and the Chikali section (Bryozoa). The lower border of the Asselian is represented in the "Plakun" section. The section "Kyn" includes the Gzhelian stage of the Upper Carboniferous and the Asselian stage of the Lower Permian. The "Filippovsky" quarry represents the Filippovsky horizon of the Kungur stage of the Lower Perm. The section "Holodny Log" is a stratotype of the cold horizon of the Asselian stage of the Lower Permian. The "Belaya Gora" is a hypostratotype of the Sakmarian stage in the Lower Permian. Irene horizon is presented in the section "Elkino" $[12,14,16]$.

\subsection{Terrestrial Permian outcrops on the protected areas}

Continental deposits are allocated towards the western and southern parts of the region. Among the most significant there are fossil sites of the Middle Permian "Chekarda" (palaeoentomology, palaeobotany) and "Ezhovo" (vertebrates) [17-19] (Fig. 3).

\section{Museum collections: the Permian Period palaeogeographical heritage ex situ}

Network of the regional and municipal museums of the Perm Region includes 38 museums, which hold in storages $1,690,330$ objects belonging to 15 types of collections. Natural history collections total amount is 73,513 objects, which is $4.3 \%$ of the total number.

Collections of the palaeographical significance are geological and palaeontological ones, with the total amount of 11,043 objects, which is $1 \%$ from the total amount. Mineralogical collections are represented in 1/2 museums of the region. More than $1 / 3$ of the region's museums complete and present items of the Permian Period (Fig. 4).

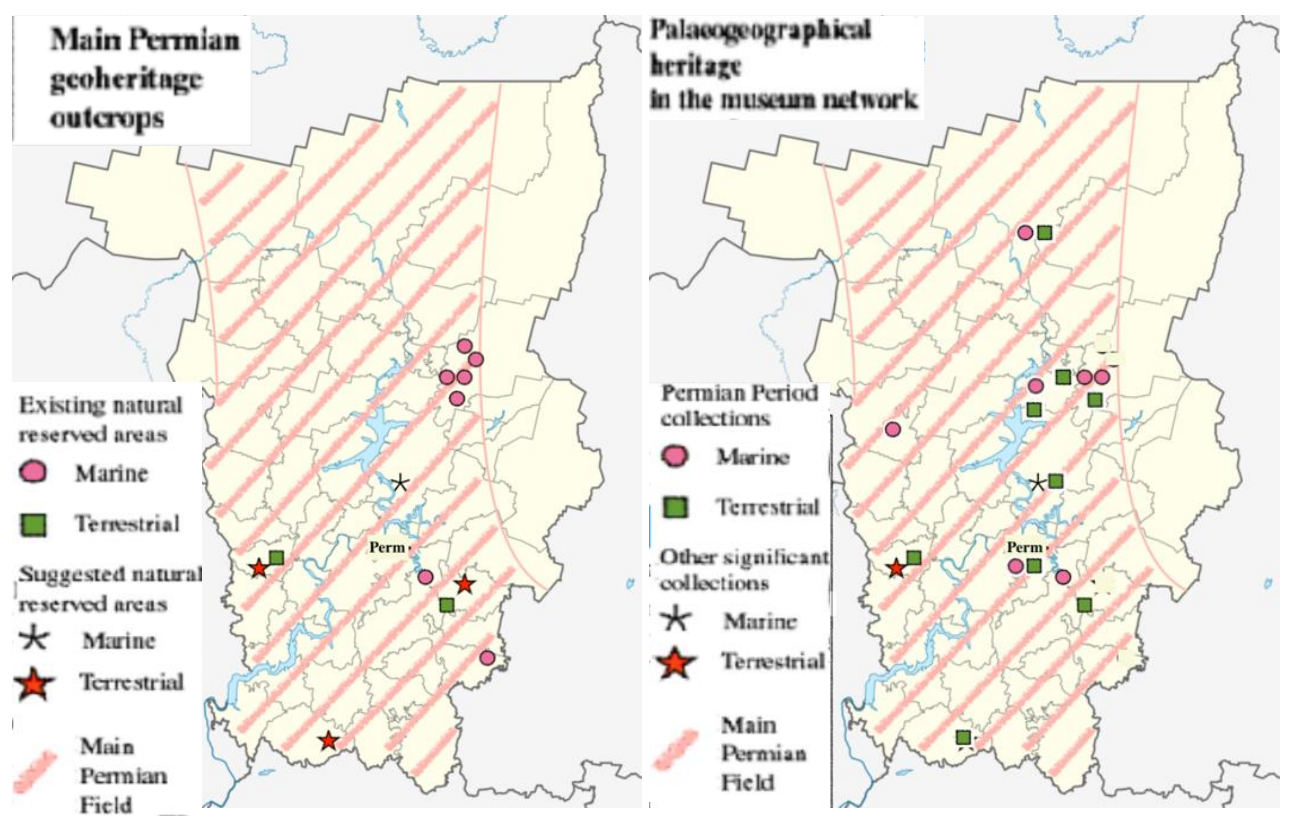

Fig. 3. Permian Period palaeographical heritage in the Perm Region: protected areas network in situ and museum network ex situ 


\section{Gaps in the Permian palaeogeographical heritage at the network of protected areas and museums}

For more than 40 years, protected areas optimization research is leading by the scientists of the Perm State University (Biogeocenology and Nature Protection Department of the Geographical Faculty and Regional, Oil and Gas Geology Department of the Geological Faculty) and by the Mining Institute of the Ural Branch of the Russian Academy of Sciences. Their joint efforts revise the existing network of the protected areas to analyse the representativeness of the geoheritage preservation efforts and suggest new geosites to be reserved under the regional and national law $[12,15,17]$.

Among them are the Middle Permian locality of fossil vertebrates, paleo-flora and paleotopes "Klyuchiki" (Kuedinsky district), Middle Permian locality of tetrapods and fossil flora "Kokuy" (Ochor district), Lower Permian locality "Polazna" (Dobryansky district), continental flora transects along the Barda river (Lysvensky district) [12, 17]. Mining geological monuments, related to the history of the Permian mineral resource development (including salts, evaporites, gypsum, copper mining, etc.), are still not represented in the protected areas network. It is expedient to create a complex protected area, specialized on palaeogeographical heritage of the Permian, based on the UNESCO Global Geopark model of sustainable development [12, 20].

Table 1. Representation of the Permian Period palaeographical heritage in the museums and protected areas of Perm Region

\begin{tabular}{|c|c|c|c|}
\hline Representation of the Permian in: & Total amount & Including Permian & Percentage \\
\hline Regional museums & 38 & 14 & $37 \%$ \\
\hline $\begin{array}{c}\text { Protected areas } \\
\text { of regional significance }\end{array}$ & 259 & 27 & $10 \%$ \\
\hline
\end{tabular}

\section{Conclusion}

Palaeogeographical identity of the Permian Period at the place of its discovery suppose a complex system dynamic representation of the territory's natural heritage in situ, on protected areas, and ex situ, in museums. Museums contain retrospective documentation of geographical diversity of the territory (natural history collections, holotypes, photo, video archives, materials scientific expeditions, etc.).

Recommendations on optimization of the protected areas network and museum acquisition is given from the point of view of palaeogeographical heritage representation:

(1) To include recommended geoheritage objects into the network of the protected areas.

(2) To strength the representation of palaeogeographical aspect in collections in the museums located within the geographical area of the Main Permian Field deposits.

(3) To complete typological objects of geological collections, including common minerals.

\section{References}

1. S.G. Lucas, S. Shen, The Permian chronostratigraphic scale: history, status and prospectus (Geological Society, London 2016)

2. V.P. Ozhgibesov, R.J. Kaffi, Tectonics and palaeogeography of the Main Permian Field and the Perm Basin of the Colorado-Mexican Paraplatform in Modeling of geological systems and processes (Perm State Univ, Perm, 1996) (in Russian)

3. International Chronostratigraphic Chart. Version 01/2020. 
4. M.J. Benton, A.G. Sennikov, A.J. Newell, Proceedings of the Geologists' Ass., 121, 313-318 (2010)

5. M. Collie, J. Diemer (eds), Murchison's wanderings in Russia. His geological exploration of Russia in Europe and the Ural Mountains, 1840 and 1841 (British Geological Survey, 2004)

6. R.I. Murchison, E. de Verneuil, A. von Keyserling. The Geology of Russia in Europe and the Ural Mountains (V.1 London, V.2 Paris, 1845).

7. C.R. Scotese, R.P. Langford, The Permian of Northern Pangea, volume 1, Paleogeography, Paleoclimates, and Stratigraphy, 3-19 (Springer-Verlag, Berlin, 1995)

8. V.I. Davydov, B.F. Glenister, C. Spinosa, S.M. Ritter, V.V. Chernykh, B.R. Wardlaw, W.S. Snyder, Episodes 21(1), 11-18. (1998)

9. The Sakmarian-base GSSP has been formally ratified (International Commission on Permian stratigraphy newsletter, 2018-08-25, 2018)

10. Three GSSP markers settled down in the Guadalupe National Park (International Commission on Permian stratigraphy newsletter, 2013-07-21, 2013)

11. G.A. Voronov, Zh.A. Chistyakova, S.P. Stenno (eds.). List of the specially protected and recommended natural territories of the Perm Region as of July 1, 1988 (Perm State University, Perm, 1989). (in Russian)

12. S.A. Buzmakov (ed.) Atlas of protected areas of the Perm Region (Aster, Perm, 2017) [in Russian]

13. S.A. Buzmakov, A.A. Zaitzev, P.Yu. Sannikov, Voprosy stepevedenia, 15. 55-58 (2019).

14. I.I. Tchaikovsky (ed.) Geological Monuments of the Perm Region. (Mining Institute of the Ural Branch of the RAS, Perm, 2009) [in Russian]

15. P.Yu. Sannikov, S.A. Buzmakov. Prospects for the development of protected areas network of Perm Region. (Perm State University, Perm, 2015)

16. G.Yu. Ponomareva, A.S. Alekseev, T.N. Isakova, O.L Kossovaya, Middle Urals. Carboniferous and Permian marine and continental successions. Field Trip Guidebook of XVIII International Congress on the Carboniferous and Permian, 36-47 (Aster, Perm, 2015)

17. S.V. Naugolnych, Geological Monuments of the Perm Region. Encyclopedia, 146-196 (Mining Institute of the Ural Branch of the RAS, Perm, 2009) (in Russian)

18. L.V. Zhuzhgova, G.Yu. Ponomareva, D.S. Aristov, S.V. Naugolnykh. Chekarda is a location of fossil insects and plants from the Permian period. Monograph on the geology; paleobotany and paleoentomology of Chekarda (Perm State University Press, Perm, 2015) (in Russian)

19. P.K. Tchudinov. Early Terapsids (Nauka, Moscow, 1983) (in Russian)

20. B.I. Chuvashov, V.A. Chermnykh, V.I. Kopnin, V.P. Ozhgibesov, P.A. Sofronitsky. Permian System: guides to geological excursion in the Uralian type localites. (University of South Carolina, Columbia, 1993) 